\title{
Nature of Conflicts, Tensions and Exploitation in Sharecropping in Rural Sindh
}

\author{
Ghulam Hussain $^{1}$, Anwaar Mohyuddin ${ }^{1}$, Shuja Ahmed ${ }^{2}$ \\ ${ }^{1}$ Department of Anthropology, Quaid-i-Azam University, Islamabad, Pakistan \\ ${ }^{2}$ Pakistan Study Centre, University of Sindh, Jamshoro, Pakistan \\ Email: mahesarg@gmail.com, unwaar@gmail.com,mahesarshuja@yahoo.com
}

Received October 11, 2013; revised November 12, 2013; accepted November 19, 2013

Copyright (C) 2013 Ghulam Hussain et al. This is an open access article distributed under the Creative Commons Attribution License, which permits unrestricted use, distribution, and reproduction in any medium, provided the original work is properly cited. In accordance of the Creative Commons Attribution License all Copyrights (C) 2013 are reserved for SCIRP and the owner of the intellectual property Ghulam Hussain et al. All Copyright (C) 2013 are guarded by law and by SCIRP as a guardian.

\begin{abstract}
This paper explains the causes of conflicts and tensions in sharecropping relationships, the nature and level of exploitation. It explains the immediate as well as root causes of conflicts that emerge between sharecroppers and landlords. Life-world of peasants of Sindh has been explored at village, sub-regional and regional level. It was found that the historical systemic structures of exploitation still exist in its refined form in peasant life-world. Peasant life within village and among village peasants is relatively peaceful. Conflicts emerge or take serious turn when outside systemic agents get involved in issues related to sharecropper and landlord. Historically property rights given to big landlords and feudal lords by imperialistic forces while snatching the indigenous right of peasants to self-cultivation, is the root cause that has spawned several sub-systemic pathologies in the life-world of peasants. Absentee landlordism, Kamdaari system, debt bondage, social bondage, system of Kann, landlessness, adulterated hybrid seeds, and issues of Sanad are some of the sub-systemic evils that have emerged over the years. All such sub-systemic structures put bigger and influential landlords into strategic advantage over the sharecroppers, particularly landless peasants; the imbalance that perpetuates "permanent liminality" suppresses reciprocal dialogues and discourages mutual negotiations. Outside systemic factors like SHO-Landlord nexus or Feudal-Police-Tapedar troika play central role in conflict creation and exacerbation in landlord-sharecropper relationship leading to bloody conflicts, caste wars, tribal feuds and honor-killings, thus, further differentiating and alienating life-world and the system rural Sindh.
\end{abstract}

Keywords: Life-World; Rationality; Conflict; Sharecroppers; Exploitation; Liminality

\section{Introduction}

This research-based explanation aims at the understanding of immediate and root causes and consequences of conflicts, tensions and the exploitation, embedded in

\footnotetext{
${ }^{1}$ The terms "sharecropper" and "tenant-farmer", as defined in English dictionaries, does not help much to define such peasants in Sindh rice belt. Sharecroppers are usually defined as having shelter and tools provided by the landlord, whereas, tenant farmer is relatively in a better position to have his own house and farming tools. Sharecropper usually is on lien, whereas tenant farmer does not take loan. Farming relationship between landowner and the sharecropper/tenant farmer is so varied and diversified, that sometimes they share certain attributes with the typical sharecropper, and sometimes with the typical tenant farmer. Here, the term "sharecropper" preferably used because in Sindh Rice Belt, sharecropper-landlord relationship is largely interdependent in nature, although most of the sharecroppers have their personal houses, yet many take input loans and tilling expense loan from the landlord and sell the crop in the market when and where landlord wishes.
}

sharecropper-1andlord relationship. It will explain the vulnerability of sharecropper and the strengths of landlords and the levels of exploitation and conflict inside village settings as well as outside village settings.

Looking in the context of rural Sindh, although Jageers ${ }^{2}$ have been legally dissolved by the government yet former feudalstill hold sway and have kept those lands under their informal control. Big landlords and the remnants of old feudal are still very much feudal in their body language, life-style, political ambitions and local authoritative rule. The bureaucrats, the police officers and even the upholders of justice have adopted the feu-

\footnotetext{
2“Jageer” was formerly, a landed area given under feudal lord's supervision to collect land revenue from peasants. Jageers, later on, virtually became undeclared property of the feudal lords, and peasants were turned into sharecroppers.
} 
dalistic mind-set as the sign of refined and elite taste. Feudalistic mentality steeped in economic as well as ethnic discrimination and snobbishness emerged out of English graft and resultantly, due to lack of mutual reciprocal dialogue, the system got disintegrated from the peasant life-world. Collective conflict resolution authority (Faislo ${ }^{3}$ by ChangaMurs ${ }^{4}$ ) and governance was more horizontal in the past became vertical, one-sided and unilateral releasing scores of social pathologies in the peasant society.

Current state of rural peasants and sharecroppers is explained here in the light of the Habermasian notion of the "Colonization of the life-world by the system" [1] and "Liminality" theory [2]. Absentee landlordism, Kamdaari $^{5}$ system, debt bondage, social bondage, system of $K a n n^{6}$, landlessness, adulterated hybrid seeds, and issues of $\mathrm{Sanad}^{7}$ are some of the sub-systemic evils that have emerged over the years. All such sub-systemic structures put bigger and influential landlords into strategic advantage over the sharecroppers, particularly landless peasants; the imbalance that perpetuates "permanent liminality" distorts communication and suppresses reciprocal dialogue and mutual negotiations.

\section{Research Methodology}

This research paper is the result of two separate yet related qualitative researches conducted in two different regions of Sindh with the purpose to look for similarities and differences in peasant-landlord relationship, conflict resolution mechanisms and to capture the peasant worldview. The data collected from the qualitative-thematic research conducted in Sindh Rice Belt on "Sharecropping, Peasant Ethic and Landlordism” has been analyzed by comparing the ethnographic field work conducted among the peasant communities of lower Sindh. Interviews from key peasant activists in Sindh had also been taken and analyzed. In the study of Sindh Rice Belt purposive nonprobability sampling was used to select and determine sample size. Study was conducted in three different geographical areas of upper Sindh rice belt in Pakistan. The team of three researchers did participant observation, conversational and semi-structured interviews, $\mathrm{FGDs}^{8}$ and individual case studies during the sowing or planting season in the flooded rice fields, in Otaqs (traditional guest houses), and Maikhanas (place for smoking and drinking).

\footnotetext{
3"Faislo", is the informal traditional and customary justice institution, arranged by the noble and honorable men from within the village community and kinship groups, called as "ChangaMurs". It is more horizontal and egalitarian than the "Jirga" system prevailing elsewhere in Pakistan.

"“ChangaMurs" is the Sindhi colloquial term, which means, "well recognized honorable men of the kinship and bradari.”

${ }^{5}$ Kamdaari is an assistance-ship of the absentee landlord, to supervise his land and sharecroppers.
}

\section{Theoretical Framework}

Theory of communicative action of Jürgen Habermas has been used as an ideal type, a methodological tool, as well as, as the main, not the sole, theoretical guiding principle to understand structural ideological and political underpinnings of peasant life-world and the system. Bolton has quoted Habermas that, "The construction of an unlimited and undistorted discourse can serve at most as a foil for setting off more glaringly the rather ambiguous developmental tendencies in modern society" [3]. Hence theory of communicative action is applied here as an ideal type in Weberian sense to assess the level of liminality, exploitation, conflict and the modernization in peasant life of Sindh.

Effort has been made to look for the possibilities of the true democratic process, to develop Habermasian ideal institutional authority based on two ways open and free dialogue between peasants, villagers, leaders and conflict-resolving institutions. Habermas proposes to promote cooperation over "strategic action" which aims at the acquisition of personal or private [4].

For Habermas rationalization of life-world is an evolutionary inevitability and a necessary social process to emancipate society. It is required assess the validity of claims on rational grounds instead of on faith [4]. The "life-world can be regarded as rationalized to the extent that it permits interactions... guided by... communicatively achieved understanding" [4]. The life-world "might remain a powerful force even as rationalized with communicative action as the predominant model of social action. But the actual result in modern capitalist societies is different: the life-world loses power at the expense of powerful forces Habermas calls system" [3].

"Liminality" theory has also been applied here to better explain social pathologies of the life-world and the system. A liminal state (or stage) is an anti-structure transitional state which produces fluid, amorphous conditions during which preceding social structures, customs and traditions are replaced by newer ones [5]. In liminal state structures, norm and values of the society get dissolved, uncertainty prevails, and events become unpredictable [6]. It is a hyper-active state of society that usually cannot lose for longer period of time.

\section{Results and Discussion}

Vulnerability of the sharecropper is the strength of the

\footnotetext{
6"Kann" is the sharecropping contractual arrangement, in which landlord is entitled to get the settled or agreed half-share of the produce, instead of usual half-share on the basis of 50:50 ratio. It is considered by sharecroppers as the extremely exploitative contractual arrangement, as even in case of natural calamities and theft, sharecropper has to pay the agreed half-share to the landlord.

" "Sanad" is the legal entitlement of the land, or the village area, a legal document to prove ownership of the landed property, or the place of residence.

${ }^{8}$ FGD stands for Focus Group Discussions.
} 
landlord who tries to extract the maximum labor from them. Social and economic crises that lead to conflict in sharecropper's life occur in situations when the land is snatched by the landlord, caste clashes and family feuds erupt, standing crop is ravaged by flood, rain, insects, animals, collected paddy grain "Raah" or domestic animal is stolen, irrigation water shortage, fine to be paid in Faisilo, Karo-kari case or scene of honor killing is created among relatives, landlord over-invoices input loan, landlord stops giving further loans, police to be bribed, fees of lawyers to be paid, family and when the gainfully employed main family member perishes.

Minor conflicts and bickering are immediately resolved through mutual negotiations. The criterion for awarding verdict is based on prevalent cultural norms and mores. A sharecropper or a landlord may have certain genuine concerns, the clarification of which may be sought by them. Concerns of sharecropper and landlord may be land-snatching, land-grabbing, misappropriation in recordkeeping, allotting the land adjacent land to another sharecropper whose house is just away from the allotted land, allegations of paddy theft, misbehavior of Kamdaar, inter-sharecropper mistrust an enmity, use of foul language or words on which there is a social taboo.

If the sharecropper and landlord may belong to the same kinship group then settlement of dispute may not take much time. Men and women of both families may mutually engage, arrange an informal meeting and settle it peacefully. Inter-caste conflicts are usually resolved by the Wadera of the village, if it gets serious, otherwise one or two reputedly wise and noble elders get together and settle it. Issues and conflicts related to sharecropping rarely get more serious than that. Landlords' prerogative to take back his land could prematurely end up escalating conflicts.

When conflicts may become serious and there may be the danger of one party inflicting serious harm on another and most of the informal efforts at its resolution fail then it is taken to the Wadera. Wadera may also take notice of such developments by himself. Cases like sharecropper injuring landlord or vice versa, allegations of theft, dacoity, threats of honor killing and rape may be resolved by the Wadera of the village. In case one of the implicated persons belongs to the Wadera's kinship group then the matter is put before another mutually agreed Wadera.

When the threats of honor killing are let to intensify it may then lead to actual killing of the alleged person. The cases of theft and rape are followed by murder. If the Wadera fails to recover protracted theft, then neutral and noble members of community (ChangaMurs) take certain deliberate efforts to pacify both parties and keep it from further escalation. They approach both parties and try to convince them to agree to Faislo. The aggrieved party usually tries to inflict similar kind of pain on the inflicting party before coming to the Faislo. To avenge the murder another murder is committed. Both fake and real cases are filed against each other till both the parties are sufficiently exhausted. The purpose behind filing cases is to make the other party suffer physically by the police and financially in terms of bribing to police, lawyers and judges.

\subsection{Nature of Conflict and Feudal Exploitation}

Inter-share-cropper clashes usually occur over irrigation water. To avoid such clashes they have evolved the system of "WaraBandi" on the basis of which watering days for irrigation are informally appointed with mutual consensus for each group of sharecroppers. But even then there remains a constant tug-of-war between upper riparian and the tail-enders. Sometimes some casualties, even murders occur over the issue of water. Sharecroppers however try not to get serious and just put an exaggerated show of aggressiveness to convince each other. Little bickering and squabbling is often sufficient to win the case. If that doesn't work then sharecroppers make groupings to steal water in the darkness of night by putting a hidden hedge in the water course to divert its flow. Sometimes casual disputes occur between sharecropper and landlord over the account of loan and expenses incurred which is maintained by the landlord. Sharecroppers can be implicated in false cases, accusation and socially boycotted if they did not obey their Wadera landlord.

Some sharecroppers who live near the land enticed by their tribal chiefs have a tendency to occupy and encroach upon the land of landlords. They do not allow any other sharecroppers to cultivate that land. They can even harass landlords and other tenants by falsely accusing them of something like Karo-kari (honor-killing and alleged honor transgression). Peasants and sharecroppers are sometimes employed by Chief Wadera and Sardaars to encroach upon the land of any landowner, small landlord or a relatively weaker big landlord. Usually Sardaars and Patharidaars ${ }^{9}$ of Baloch tribes entice their peasants to encroach upon other's property. Landed property of mild and mutually coexisting ethnic Sindhi tribes to encroach upon by Baloch tribes whose past history and traditions sometimes allow them to encroach, grab and snatch with the tacit approval of Sardaar, or Patharidaar-Wadera.

\subsection{Seed Choice; Hybrid v/s Traditional}

During the process of development subsistence economies change into market economies and the people switch

\footnotetext{
9"Patharidaar" or "Patharidaar-Wadero", are the criminal characters, like the underworld Dons of the urban centers. They tame dacoits and thieves, and through them control the local police and exploit the sharecroppers, landless peasants and the villagers.
} 
over from the subsistence to the cash crops [7,8]. After green revolution in 1960s and the introduction of IRRI varieties rice in upper Sindh and Mexican wheat in the lower and middle Sindh have become major cash crops and staple foods of the regions [9]. But now IRRI varieties are probably replaced by some other hybrid varieties, the issue of serious concern for farmers, growers and the peasant activists. There were times when rice used to be cultivated for subsistence. Traditional and indigenous aromatic varieties of paddy like BidriGulab and Basmati were common but now such old varieties have become extinct and the time-tested IRRI varieties are also being adulterated and eliminated making peasants directly dependent on local and foreign, usually western, hybrid seed companies. Paddy is now cultivated not only for subsistence but also to earn substantial income. That has made both small farmers and landlords greedy particularly the latter.

In informal meetings before actual interviews were conducted some sharecroppers told researchers that they had recently been threatened by a landlord of dire consequences if they did not obey his commands. Landlord was in fact forcing them to grow the hybrid seed which is relatively expensive whereas sharecroppers wanted to grow local varieties of seed. Four tenants who collectively cultivated 18 acres of land, in fact abandoned sharecropping, some others threatened to leave if the landlord did not revoke his decision. In the end sharecroppers won the point and finally they were allowed to grow local seed varieties which were less expensive and trustworthy. This clearly demonstrates the freedom and independence of tenants and the forceful insistence of landlords for vested interest. They are not always coerced to do tenancy at any cost. Yet, in usual cases, landlords usually force sharecroppers to purchase the seed of their choice i.e. certified hybrid variety. Hybrid seed is five times expensive that of local traditional seed varieties. Yield from hybrid seed is normally 20\% more than the local traditional “IRRI” or “DR”, Danglo and RoosiKarnal varieties. Despite of the high yield hybrid varieties the net income of a sharecropper from these varieties (Rachna, Guard, Pukhraaj, Komal, and AliAkbar) remains just the same due to the expensive seed purchase and extra fertilizer application. In that way landlord definitely earns slightly more profit but the profit differential for sharecropper is either just the same or even less than that of traditional varieties. Because of the fact that hybrid seed is highly expensive and beyond the purchasing power of the sharecropper, landlord forcibly purchases it for the sharecropper and coerces him to sow it. Sharecropper is left with no option except to oblige the landlord or to revoke sharecropping. Sharecroppers want that cost of hybrid seed should be borne equally by the landlord and sharecropper. Many sharecroppers believe that yield and income differentials are just marginal in terms of seed varieties. Therefore it is deemed wise by them to grow locally purged traditional varieties.

\subsection{Kann and Serri: Systemic Ploy}

Kann is the system of sharecropping in which landlord is entitled to get the agreed share of produce whether the land or cropping produces more than the expected or agreed share or not. In case of natural calamities, damage to crop by animals or humans and even theft of some of the produce, landlord would get his due share. In kann landlord is entitled to get the agreed share of produce usually slightly more than the expected half yield. Landlord could get his share of the produce as per agreement even if the yield is less than what was expected. Similarly sharecropper would get what is left after the landlord's share has been deducted even if the yield is more than what was expected. None of the sharecroppers seemed willing to accept sharecropping on terms of Kann. Neither any landlord was reported to have recently offered his land on Kann. Sharecroppers have always been against that system and they wanted to get rid of it. In several villages of Sindh Rice Beltthat system has recently been abolished by the landlords after the sharecroppers' peaceful non-cooperative resistance. But where the landlordism is still strong, it has been kept continue.

Similar to the system of Kann and unpaid labour (begar) in Sindh rice belt the system of Serri prevails in lower part of Sindh. Peasants belonging to outcaste Hindu minorities have to irrigate and crop an extra land of the landlord on his behalf without being paid under Serri [10, 11]. Serri is still well entrenched exploitative institution whereas the Kann is near to its demise as the landed property of landlords gets distributed internally through familial division and distribution.

\subsection{Issue of Sanad}

Issues of Sanad (legal title to own house and village area) did not emerge in the distant past when the peasant lifeworld and the system were less differentiated. People owned houses in the village just by being indigenous members of residing kinship group. Land allotment was informal and customary. Although the village land in most cases belongs to the statenow, yet Waderas and big landlords try to maintain hegemony over villagers and village land. The person who voluntarily migrates or forced by the Wadera to migrate to another village or the city cannot sell his plot to anybody except his close relative or a Wadera himself. Houses abandoned by sharecroppers of Wadera himself or by common villagers belong to Wadera landlord only. He may use them for his own purposes. That has been the most common pattern since centuries but now village people are more aware 
about their rights and some instances of retaliations have been reported. In one instance Wadera was forcing the village Jogis (professional beggars) to evacuate the village as the land had been lease by the landlord, in the name of peasant-relative, from the government under land reform program. Jogis had abodes over that land since more than fifty years. They faced the landlord, fought the case and won the Sanad. Jogis did not seem to evacuate the village in future. Jogis, however, did not achieve their goal single handedly. Intervillage and inter-tribal and ethnic politics played the major role. Many Jogis were helped by the literate and influential members of their caste belonging to other villages and areas in that case. They were also assisted and made bold by the cooperation by neighboring PatharidaarWadera. Above case proves that multiple factors determine land arrangements.

\subsection{Land Registration and Encroachment}

Although peasants in Sindh Rice Belt in particular, and throughout Sind in general, do not feel compelled to get their houses and lands compulsorily registered, the "obsolete record management system and peasant's vulnerable position (low-literacy, lower status) [nevertheless] deprive them of the access to registration and documentation process" [12]. That clearly shows the governmental legal system's incompatibly with the real life lived experiences of the villagers.

Land registration is still a non-issue in Sindh rice belt. Most of the small landlords and landowners own lands not formally documented in their names but they still own it in the name of grand-grandfathers. Some former sharecroppers were reported to have encroached upon lands of the small landowners and they are cultivating it since several generations but such encroached lands are still registered in the former landowner's name. In that case former sharecroppers have become landowners themselves without being fully registered. Any complaint by former landowners to Mukhtiarkaar usually falls flat and ultimately turns to be inconsequential as the lands are in the physical and geographical proximity of encroachers and away from the former landowner's reach. Any village property or landed area, when it is occupied by any party, either legally or illegally, cannot be easily claimed back in the Sindh Rice Belt. But such occupations and encroachments are rare and mostly ownership rights are well protected by tribal, cultural norms, and customary laws of the Sindhi peasant society.

\subsection{Role of Kamdaar in Conflict Resolution}

Landlords who had more than 30 acres of land usually appoint Kamdaar (Assistant to supervise fields on behalf of landlord and to report him). Kamdaar keeps all or some of the record of expenses, labor, investment and wages related to cultivation activities. Some landlords do not appoint Kamdaar and instead look after all the related issues themselves including record-keeping. Sharecroppers compete with one another for getting suitable piece of land and for that purpose they, sometimes, resort to unfair tactics. They poison ears of landlord and Kamdaar or of landlord's favorites against one another. Kamdaar is sometimes bribed few thousand rupees by one of the competing sharecroppers to make to win the favor of landlord. Sharecroppers usually like establishing close and direct relationship with the landlord and usually dislike Kamdaar

Some landlords who also do self-cultivation declare themselves as Kamdaars and deduct their share of kamdari or supervision from the sharecropper's share at the time of distribution. Kamdaar is usually on good terms with some sharecroppers, while on bad terms with some others. His role in land-snatching and land-allotting is pivotal. Sharecroppers try to keep him happy and contended. Kamdaars can prove to be the worst exploiter of an absentee landlord. In the absence of a landlord he is a virtual owner of the land. Many a time Kamdaar, in collusion with one or two sharecroppers confiscate paddy or hay or sell it secretly in the market. Earned income is then either equally shared with the sharecropper or under-invoiced by the Kamdaar.

\section{Theoretical Discussion}

The concept of life-world, as defined by JürgenHaberman, better explains the Sindhi Peasant's worldview, peasant-culture, sharecropper-landlord conflicts, and role of systemic agents like the police, Wadera, and feudal lords. "To Habermas the life-world represents an internal perspective [of peasants and villagers] (while... the system represents an external viewpoint [of the state, government, police, and the feudal]... [peasant] society is conceived from the perspective of the acting subjects [peasants]. Thus, there is only one society; life-world and system represents an external viewpoint” [13]. "The lifeworld so to speak, is the transcendental site where speaker and hearer meet, where they reciprocally raise claims that their utterances fit the world... And where they can criticize and confirm those validity claims, their disagreements, and arrive at agreements.” [14]. "By 'system' Habermas means an external viewpoint or external perspective that views society from the observer's perspective of someone not involved" [13].

"The system has its roots in the life-world but ultimately it comes to develop its own structural characteristics. Examples of such structures include the family, the judiciary, the state, and the economy. As these structures evolve, they grow more and more distant from lifeworld... these rational structures instead of enhancing the 
capacity to communicate and reach understanding, threaten those processes through exertion of external control over them" [13].

For Habermas, "subsystems of money, power, administration and bureaucracy have got reified. Political (power), economic (money) and administrative (bureaucracy) system "burst the capacity of life-world they instrumentalize... that results in the violence which in turn produces "pathologies" within the life-world [13]. Such pathologies in peasants' perspective could be PatharidaarWadera, SHO-Wadero-Dacoit nexus, system of Kann, Bhoongo, imported hybrid seeds, water theft, honor killings, caste wars, serri (unpaid labor in lower Sindh), debt bondage, social bondage, landlessness, casteism, tribalism, feudalism and the institution of sharecropping itself.

\subsection{Landholding and Landlessness}

The biggest historical and structural exploitation that was implanted in the body politic of Sindhi peasantry was the sudden systematization of landed property by Mughals and later on by the East India Company through the introduction of the institutions of Jageers (feudalism) and Zamindari (Landlordism) thus disenfranchising indigenous owners of the land that is peasant proprietors and turning them into sharecroppers. Property rights of landlords over land in access of their economic potential are one of the major causes of underproduction, poverty exploitation and conflicts [15]. Absentee landlords let their Kamdaars (managers) manage their lands who in fact serve as the prime tools of direct exploitation of the sharecropper. In Sindh peasant exploitation is being perpetuated by the absentee landlords who instead of taking cropping seriously indulge into leisurely parasitic social activities [15]. Apparently its borrowing and lending of loans that traps sharecroppers into debt bondage, seems to be the major factor and immediate cause of exploitation of sharecropper and creates rifts between landlord and sharecropper and although the role of Kamdaar in creating rifts between sharecroppers and between sharecropper and the landlord ( the direct result of absentee landlordism) is also of much consequence, yet major factor, the root cause is the ownership of land or the lack of it, that is landlessness which gives virtual power to landlord over sharecropper and puts the former in a permanent strategic advantageous position. Permanent strategic advantage has created a perpetual liminal crises in which trickster landlords in collusion with systemic administrative (police, Mukhtiarkar), bureaucratic, legislative $\left(\mathrm{MNAs}^{10}, \mathrm{MPAs}^{11}\right.$, feudal ministers), and rational legal (advocates and judges) permanently exploit the sharecroppers and landless peasants. Liminal situation pre-

\footnotetext{
10"MNA", stands for "Member of National Assembly".

11"MPA", stands for "Member of Provincial Assembly.
}

cipitates the collapse of system unless the older worldview is replaced by the newer one and people stop asking fundamental questions of life [2]. All major events in the history, revolutions, social and political movements that brought about change in the structure of the system can be said to be liminal states of society [2]. In liminal state individuals are unable to think rationally and objectively and adopt herding behavior that is blind imitation and reproduction of dominant discourse produced by the pseudo-leaders or the tricksters from the outside [5]. But in rural Sindh liminal state has been relatively permanent [2] under control of outside systemic tricksters.

\subsection{Landless Outcaste Peasants}

Sharecroppers of lower Sindh are probably the most marginalized and ethnically discriminated liminal identities who have been pushed to the borders and margins of the core dominant cultures. Most of the sharecroppers in lower Sindh belong to the landless, ethnically and religiously discriminated Hindu untouchable castes that tend to migrate and forced by chronic drought from desert of Tharparkar [10]. They are temporarily settled on the lands provided by their Sindhi-Muslim landlords. Their vulnerable social and economic status due to landlessness and insecurity of tenancy contract tempts landlords to trap them into debt bondage. Debt bondage further leads to social bondage in which the whole peasant family serves landlords just like slaves. In extreme cases suspicious and rebellious sharecropper-families are even chained or imprisoned [16]. Hindu untouchables even the lack the strong cover and defense that is provided to other Muslim castes by their respective caste and bradari ${ }^{12}$ affiliations and their kinship ties with landlord families. Hence theirs' is the extreme and permanent liminal state in which life-world and the system are extremely polarized and differentiated. Liminality in landlord-sharecropper relationship in Sindh Rice Belt in Upper Sindh is not much evident whereas in other matters related to bradari and caste feuds; it may become evident when big landlords, police, state-courts and tribal chiefs get involved in conflicting situations.

\footnotetext{
12“Bradari” or a kinship group in Sindh Rice Belt has multiple connotations depending upon the levels of affiliations. At the most intimate level, Bradariis a kinship group intermarrying households, both maternal and paternal, which usually reside close proximity in an internally linked neighborhood (Paara) with lower boundary walls. They tend to share, reciprocate, and exchange goods, services, secrets and emotions routinely. At another dispersed level, the caste-group of the same village takes the form of Bradari, when inter-caste issues erupt in the village. In matters of inter-village importance, the whole village is considered a bradari. In matters of caste wars or feuds, the whole caste is taken as a Bradari. Bradari is also taken in the connotation of the Punjabi "Panchayat", when any serious is settled in informal courts (Jirga/Faislo). In that case, both competing bradaris, together with the honorable decision-makers or judges are taken as Bradari.
} 


\subsection{Importance and Relevance of Sanad}

To advocate that villagers and sharecroppers should have a sanad to prove their ownership [12] remains irrelevant till some inter-landlord or inter-Sardaar politics from systemic agents manipulates the situation for their private ends. In Sindh Rice Belt to evacuate somebody even of a minority low-caste Jogi tribe is extremely difficult even for a powerful Wadera. In a society bonded together through bradari and caste affiliation and influenced by tribal culture, having a sanad or not, is usually inconsequential. That is one of the reasons that most villagers even wealthy and independent or well educated ones do not keep sanads. Village plotting and housing records are updated through collective recalling by elders and transferred from one generation to another. Words of mouth, oral testimony and oaths on holy book generally decide ownership rights in case of conflict. In fact they rarely need to prove that they are owners of their house. Almost everyone in the village knows who owns what and since when. Community consciousness or community sentiment usually determines socialrelations in villages.

Land encroachments are rare and mostly ownership rights are well protected by tribal, cultural norms, and customary laws of the Sindhi peasant society. Encroachments have been made extremely difficult by overarching protective social network based on Biradari, cast and tribal affiliations. But whenever it so occurs, it occurs at the behest of forces outside the village that are not immediately affected by such conflicting situations. Such outside systemic factors are SHO-Landlord nexus or FeudalPolice-Tapedar ${ }^{13}$ troika. They game played by outsiders consequently leads to bloody conflict, caste wars, tribal feuds and honor-killings thus further differentiating and alienating sharecropper's life-world and the system.

\subsection{Hybrid Seed: Assault from the Global North}

The choice of doing away with hybrid seed has serious economic, social, cultural, regional, ecological and agricultural and food-related implications. Peasants in Sindh are probably unconsciously following in the same natural line as suggested by South American peasant activists. They are stressing on the production and preservation of local indigenous seeds varieties that are also more ecofriendly [17]. They are stressing the use and production and consumption of locally produced foods like churned butter, lassi (cold drink made of churned milk), milk, rice and wheat. Theirs is the stance in line with the notion of "food autonomy" which emphasizes the specific rights of communities and agro-ecological regions to freely choose the consumption and production of local foods [18].

\footnotetext{
13“Tapedar" is the administrative officer authorized by the government to collect land revenue, water tax and keep land records of the area, called “Tapo”.
}

Peasant movements of Sindh such as Chambar peasant movement and HariHaqdaar movement like international peasant movement "Via Campesina" are rooted in cultural values of "social justice... to ensure future without hunger” [19]. Peasant movements of Sindh have launched campaign against the reductionist market-based approach to agriculture to ensure food security [17]. "As the food sovereignty movement demonstrates market supply meets corporate rather than human needs - corporate food production does not address or generate demand so much as generate hunger. Market control in the name of development systematically violates the rights of people of the land to co-exist and secure the social reproduction of the majority of the world's people, and practice ecological sustainability” [20].

\section{Conclusions}

In sharecropping tensions may erupt on the issues of land-snatching, land-grabbing, water-theft, misappropriation in record-keeping, allotting the land adjacent to another sharecropper whose house is just away from the allotted land, allegations of paddy theft, misbehavior of Kamdaar, and due to that the inter-sharecropper mistrusts an enmity. Settlement of disputes in sharecropperlandlord relationship is determined by multiplefactors which may include relative economic strength, social influence, kinship ties, tribal status, caste affiliations and the nearness or proximity of land under cultivation. Noblemen from the Kinships play pivotal role in pacify overt conflicts. Formal rational legal means are resorted to cases when outside systemic forces intrude into sharecropper's life matters. In such situations conflicting parties, landlord or the sharecropper, tries to make the other party suffer physically as well as financially by police, lawyers, and judges.

Peasants in Sindh are following in the same natural line as suggested by South American peasant activists. They are stressing on the production and preservation of local indigenous seeds varieties and are discouraging the use of imported hybrid seeds that are not only adulterating localindigenously preserved seeds but are also more capital-intensive and less eco-friendly. Similar to the system of Kann and unpaidlabour (Begar) in Sindh rice belt, the system of Serri prevails in lower part of Sindh. Serri is still well entrenched exploitative institution whereas the Kann is near to its demise due to sharecropper's resistance and as the landed property of landlords gets distributed internally through familial division and distribution hence indicating the positive change towards rationalization of life-world and the restraint of the system. Issues of Sanad (legal title to own house and village area) did not emerge in the distant past when the peasant lifeworld and the system were less differentiated. 
Property right of landlords over land in access of their economic potential however is one of the major causes of underproduction, poverty exploitation, minor tensions and serious conflicts. Absentee landlords let their Kamdaars (managers) manage their lands who in fact serve as the prime tools of direct exploitation of the sharecroppers. Thus the root cause of inequality, exploitation and the colonization of peasant-village lifeworld is the ownership of land or the lack of it, that is landlessness that gives virtual power to landlord over sharecropper and puts the landlord in a strategic advantageous position.

Above research-based explanation was aimed at the understanding of immediate and root causes and consequences of conflicts, tensions and the exploitation embedded in them. Landlord-sharecropper relationship is intricately interwoven with the peasant life, folk traditions, peasant ethic, village settings, rural economy and the historical structural arrangements. It was found that vulnerability of the sharecropper is the strength of the landlord who tries to extract the maximum labor out of $\mathrm{him} / \mathrm{her}$. The extent of exploitation however is minimal within and among sharecroppers and the small landlords of the same village where power relations are more horizontal due to the impact of bradari and kinship ties. Despite that the relatively dominant position of the landlords being the owner of the land cause tensions and rifts between sharecropper and landlord. Tensions between sharecroppers and small landlords rarely erupt in serious confrontation in Upper Sindh whereas in Lower Sindh where peasant-landlord relationship is more liminal and polarized, sharecroppers assisted by peasant activists (supporters of peasant worldview) sometimes openly resist. Minor conflicts and bickering are immediately resolved through mutual negotiations. Hence, the life-world and the system (traditional institutions holding peasant kinship system and bradari together) are less differentiated and more reciprocal. Liminality in landlord-sharecropper relationship in Sindh Rice Belt in upper Sindh is not much evident. Whereas in other matters related to bradari and caste feuds, it may become evident when big landlords, police, state-courts and tribal chiefs get involved in conflicting situations. Social bondage, system of Kann, marginalized role of nobles from within peasants and the dominant role of Wadera and Sardaar are manifestations of distorted communication, lack of dialogue, egalitarian attitudes and intrinsic values of folk peasant life.

\section{REFERENCES}

[1] G. Ritzer, “Sociological Theory,” 8th Edition, McGrawHill, New York, 2011.
[2] B. Thomassen, "The Uses and Meanings of Liminality," International Political Anthropology, Vol. 2, No. 1, 2009, pp. 5-28.

[3] R. Bolton, "Habermas's Theory of Communicative Action and the Theory of Social Capital. Regional Science Association,” San Diego, 2005, p. 39.

[4] J. Habermas, "Reason and the Rationalization of Society,” Vol. 1, Beacon Press, Boston, 1984.

[5] A. Szakolczai, "Liminality and Experience: Structuring Transitory Situations and Transformative Events,” International Political Anthropology, 2009.

[6] A. Horvath, B. Thomassen and H. Wydra, "Introduction: Liminality and Cultures of Change,” International Political Anthropology, 2009.

[7] A. Mohyuddin, H. R. Chaudhry and M. Ambreen, "Economic Structure of a Village in Balochistan: World System Analysis at Micro Level in Anthropological Perspective," International Journal of Economics, Commerce and Research, Vol. 2, No. 3, 2012, pp. 79-98.

[8] A. Mohyuddin, H. R. Chaudhry and M. Ambreen, "Economic Empowerment of Women in the Rural Areas of Balochistan," Pakistan Journal of Women's Studies: Alam-e-Niswan, Vol. 19, No. 2, 2012, pp. 239-257.

[9] G. Haris, K. Ayesha and K. Themrise, "Land Tenure, Rural Livelihoods and Institutional Innovation,” 2002.

[10] Bhandaar Sangat, "Porihiat: Chambar Hari Tehreek," Special Edition, Hyderabad, 2012.

[11] Bhandaar Sangat, “Reports,” 2013. http://www.bhs.org.pk/home

[12] PILER, "Labor Rights in Pakistan: Declining Decent Work and Emerging Struggles,” Pakistan Institute of Labor Education and Research, 2010.

[13] G. Ritzer, “Sociological Theory,” 4 Edition, McGraw-Hill Companies, Inc., 1996.

[14] J. Habermas, "Lifeworld and System: A Critique of Functionalist Reason,” Vol. 2, Beacon Press, Boston, 1987.

[15] M. Khadarposh, "Jinen Daand Na Bijj (Hari Report)," Naqoosh Press, Urdu Bazaar Lahore, 2002.

[16] Bhandaar Sangat, “Case Studies,” 2013. http://www.bhs.org.pk/casestudies/

[17] B. H. Sangat and G. B. Oxfam, "People's Declaration of Agrarian Reforms,” Pamphlet. Hyderabad, Sindh, Pakistan: Bhandar Hari Sangat, 2012.

[18] A. Escobar, “Alternatives to Development': An Interview with Arturo Escobar,” Venice, 2012.

[19] L. V. Campeina, "Declaration of Rights of PeasantsWomen and Men,” Jakarta Selatan, Indonesia: J. I. Mampang Prapatan XIV No. 5.

[20] P. McMichael, "Peasants Make Their Own History, but Not Just as They Please...,” Journal of Agrarian Change, Vol. 8, No. 2, 2008, pp. 205-228. http://dx.doi.org/10.1111/j.1471-0366.2008.00168.x 